\title{
SUPPORT FOR CRISIS MANAGEMENT AT THE TIME OF FLOODS
}

\author{
MARTINA ZELEŇÁKOVÁ ${ }^{1}$, MÁRIA ŠUGAREKOVÁ ${ }^{1}$ PETER MÉSÁROŠ² \\ ${ }^{1}$ Department of Environmental Engineering, Technical University of Košice, Slovakia \\ ${ }^{2}$ Department of Construction Technology and Management, Technical University of Košice, Slovakia
}

\begin{abstract}
This paper is focused on assessing the effects of floods on selected components of the environment. The components include the impact of floods on the population, water conditions, soil, fauna, flora and their habitats, the structure and use of the landscape, protected areas and their protection zones, for the territorial system of ecological stability, for the urban complex and land use, for cultural and historical monuments, cultural values of an intangible nature and for archaeological and paleontological sites and important geological localities. The basic principle of the methodology is the calculation of the risk index - an estimate of the level of risk that the proposed activity represents for the environment. The risk analysis is based on the principle that stressors are associated with the proposed activity, which poses a certain risk to the components of the environment. This can be quantified by calculating the individual risk for each identified environmental impact of the stressor. In summary, the total risk can be calculated, which represents what risk the proposed activity poses to the environment and human health. The calculated value of total risk represents very low level of risk in the addressed river basin. As a proposal for measures in the event of floods, a Draft Protocol providing health and social care in case of floods is created. The Draft Protocol may be used as a supplement to the Flood Management Plan from the point of view of providing health and social care.
\end{abstract}

Keywords: environmental components, flood, flood impact assessment

\section{INTRODUCTION}

The area of Central Europe is often affected by natural elements, most often by flood situations. The events from 2010, when the territory of the Slovak Republic was hit by the most devastating and largest flood in the last decade, are in fresh memory. Slovakia belongs to the countries which are increasingly being affected by floods Zeleňáková [1,2]. The study by Mishra and Sinha [3] proves that floods are one of the most devastating natural disasters, causing enormous damage to property and, in some cases, loss of life. Technical flood control measures are being built in the municipalities of Slovakia to prevent a devastating subsequent river basin. However, it is also important to manage the flood situation in terms of providing health and social care to the affected citizens/residents of the affected area. There are several possible methods to assess the flood risk in the affected area. The study by Vojtek and Vojteková [4] described a case study on flood hazard and flood risk assessment at the local spatial scale using geographic information systems, remote sensing and hydraulic modelling. The approach to assessment by Tsakiris [5] is based on a new systemic paradigm. Special emphasis is given to the urban areas with mild terrain and complicated topography, in which 2-D dully dynamic flood modelling is proposed. The methods used in this paper is based on flood risks assessment according to FEIRA process.

The main goal of this paper is to create a proposal document providing health and social care in case of floods in affected area. This proposal is the result of the flood risk assessment according to the FEIRA process consists of the following steps: description of current state of the environment, definition of the source of pollution in the area, identification of stressors and calculation of probability, consequence and the final risk. 
(1) description of the current state of the environment,

(2) definition of the sources of pollution in the area,

(3) identification of stressors,

(4) calculation of probability, consequence and the final risk.

The impact and assessment is focused on the territory of the Hornád river basin located in the territory of the Slovak Republic. The case studies describe the methods for dealing with flood impact assessments in some countries, as well as the methods used, resp. proposed solution methodology.

The following chapter is devoted to the description of the solved area - the partial catchment area of Hornád river, to which the practical part of this work applies.

\section{STUDY AREA}

The Hornád river basin (Fig. 1) covers the territory of the Slovak and Hungarian Republics with a total area of $4,414 \mathrm{~km}^{2}$ and a length of $193 \mathrm{~km}$ in Slovakia and $93 \mathrm{~km}$ in Hungary.

The area of the Hornád sub-basin is characterized by the occurrence of impermeable and poorly permeable rocks, which have a moderate to low permeability. Rocks with good to high flow can be found in the Košice Basin and in the areas of the Slovak Karst and the SpišGemer region. The rocks in the area of the Slovak Ore Mountains and Branisko are poorly

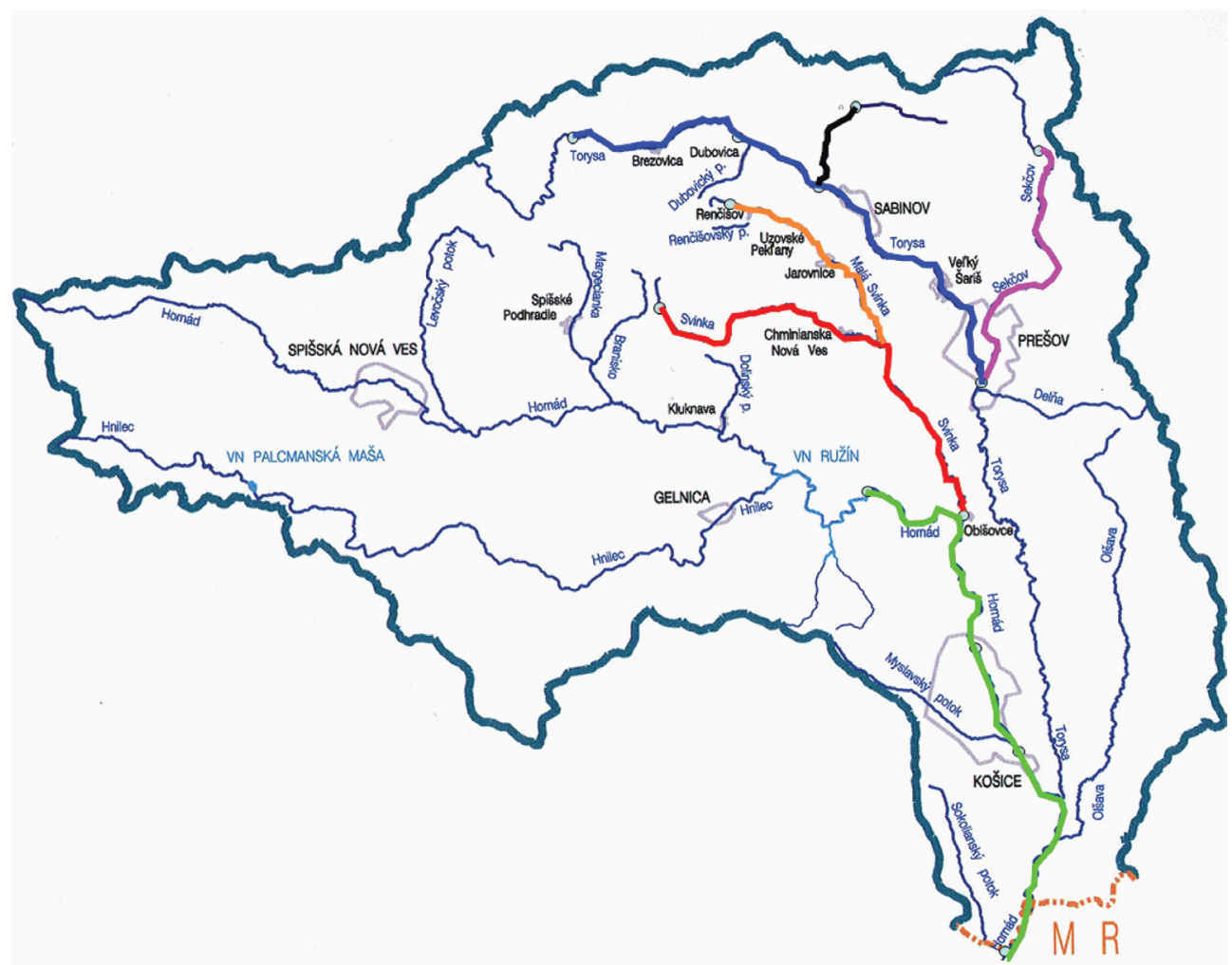

Figure 1: Study area - Hornád river basin. 
permeable with a predominant fissure permeability. Atmospheric precipitation is the main source of groundwater in this area [6].

Part of the Hornád basin is located in the province of the Western Carpathians, a sub-province of the Inner Western Carpathians, and a smaller part of it belongs to the sub-province of the Outer Western Carpathians.

The sub-province of the Inner Western Carpathians includes the area:

- Slovak Ore Mountains,

- Fatra-Tatra region,

- Lučensko-Košice reduction,

- Matransko-Slanská area.

The areas belonging to the sub-province of the Outer Western Carpathians are the Eastern Beskydy and the Podhôlno-Magurská area.

The highest altitude of 1,401 m asl. occupies the smallest area of the solved area, the largest area lies at an altitude of 300-500 $\mathrm{m}$ asl. [6].

Due to the geographical location of the Hornád sub-basin, there are up to three climatic areas. The warm to slightly dry climatic part, characterized by a cold winter, includes the southern to south-eastern area bordering the Sabinov area. The middle part of the basin is characterized by an average total precipitation from 700 to $900 \mathrm{~mm}$. The climatic conditions in this district are slightly warm, slightly humid to humid. The area bordering the Volovské vrchy is characterized by a slightly cold climate. The air temperature here ranges from $4^{\circ} \mathrm{C}$ to $5^{\circ} \mathrm{C}$. The annual total precipitation also exceeds $900 \mathrm{~mm}$ [6].

The Hornád river basin covers an area of two states. In the territory of the Slovak Republic, together with its tributaries, it occupies $81 \%$ of its total area. The most important right-hand tributary is the river Hnilec, which flows near the village of Margecany. Hnilec springs on the slope of Král'ová hol'a at an altitude of approximately 1,740 m asl. It flows into the Palcmanská Maša reservoir, which is also the largest reservoir in the Slovak Paradise National Park. The flow of Hnilec continues from the dam in an easterly direction to the Ružín reservoir.

The most significant left tributary is created by the river Torysa near the village of Nižná Myšl'a. It springs in Levočské vrchy, northwest of the village Torysky at an altitude of approximately 1,215 m asl. Torysa flows south, flowing through the city of Prešov [6].

Slovakia is a country which, due to its size, belongs to smaller states. Nevertheless, on the territory of this republics is possible to find natural but also historical monuments, which are exceptional due to their origin. There are also a number of natural and cultural monuments in the Hornád river basin belongs to the world's top.

(1) Breakthrough Hornád river - is a section of the upper course of the Hornád river, which is approximately $16 \mathrm{~km}$ long.

The canyon-like valley was created by cutting the Hornád river predecessor into a ridge. At the end period of the Late Neogene, the bottom of the Hornád river basin gradually decreased, while the territory the Slovak Paradise was gradually rising. The banks of the valley are lower soon in this time period by $300 \mathrm{~m}$ compared to the side ridges [6].

(2) Herl'any geyser - is situated in volcanic hills, was artificially activated in the 19th century due to the need to provide healing mineral water for the creation of spas. The well is deep $404.5 \mathrm{~m}$, is characterized by low-thermal water. A water eruption appears in the well every 34-36 h, when the water changes to a height of $15 \mathrm{~m}$. The geyser is supposed to be continued to operate until it is mechanically damaged. Its yield depends on atmospheric conditions [7]. 
In the solved area lies the second largest Slovak city of Košice - the metropolis of the east. The city lies on the edge of the Košice basin on the Hornád river. The historic square is one of the city's largest monuments reservations in Slovakia. The dominant element in the middle of the square is the Church of St. Elizabeth characterized as the largest church in Slovakia. The city hosts an annual International Peace Marathon. This event belongs to one of the oldest in Europe. The historically rich city in the solved area is also the city of Levoča. Its monuments include the Church of St. James, which is also a national cultural monument and the second largest church in Slovakia. The altar in the church is the work of Master Paul of Levoča. His works are known to the general public and are also cultural monuments [6].

The following part of the work is devoted to the methodology of assessment and analysis of individual factors affecting selected components of the environment. The final part summarizes the final values of the assessment and the overall assessment of the impact of floods on the area, as well as the assessment of flood risk.

There are several industrial sites in the Hornád sub-basin, which may pose a risk of environmental pollution in the event of floods. Summary Table 1 lists these sources of pollution. In the event of a flood at Q100, several industrial sites pose a direct threat to humans but also to the environment. Namely they are:

- Area of VSE - company of mechanical production Krompachy - group unclassified,

- Wastewater treatment plants (WWTP): WWTP Harichovce, WWTP Vajkovce, AGROKOV PLUS Košice, WWTP Rožkovany, WWTP Jakubova Vol'a - group of wastewater treatment plants up to 2,000 equivalent populations,

- WWTP Spišské Vlachy, WWTP Flood yard Krompachy, WWTP IMUNA PHARM Šarišské Michal'any - group of wastewater treatment plants from 2,000 to 10,000 equivalent populations,

- WWTP Spišská Nová Ves - group of wastewater treatment plants from 10,000 to 100,000 equivalent populations,

- KOVOHUTY Krompachy - group probable environmental burden,

- SEZ Krompachy - electrical production plant - group of remediated/reclaimed locality.

Each pollution source is assigned an appropriate number of points according to the categorization.

\subsection{Flood activity in Slovakia}

\subsubsection{Year 2009}

The most common causes of floods in 2009 were torrential rains with a high intensity, which flooded the territory of the Slovak Republic in the summer months, flooded the Dunaj basin river in March and June, the occurrence of rains during the snowmelt period and ice barriers. Floods occurred quite unevenly. At the beginning of the year, floods occurred due to the thawing of watercourses, later, floods caused by warming and subsequent snowmelt were added. Intense the precipitation that occurred in Slovakia brought with it two waves of floods in the summer months. During the autumn, no degree of flood activity was declared, but the arrival occlusion front and a sudden warming in December again indicated the emergence of a flood situation. During the year 2009 in the Košice and Prešov self-governing regions was declared III degree of flood activity with a total of 106 times. In selected districts of the Košice and Prešov self-governing regions, III degree of flood activity declared 36 times [8]. 


\subsubsection{Year 2010}

At the beginning of summer in 2010, the territory of Slovakia was accompanied by intense rainfall. For a few monthly precipitation records were broken by precipitation metre stations. Floods that occurred in May and June in Slovakia, were from a hydrological point of view due to temporal and spatial layout extraordinarily. Almost all river basins throughout the territory have been affected. In eastern Slovakia, the Hornád river in Margecany had a flow of more than 10 years, in some areas there was even a flow of 50-100 years of significance. About the significance of this year in terms of the occurrence of floods is also evidenced by the number of declarations III degree of flood activity. In the basin of Hornád river was declared for 2010 a total of 234 times [8]. This year was extraordinary in terms of the occurrence of floods and the floods caused damage especially to Eastern Slovakia.

\subsubsection{Year 2011}

In the first half of March, heavy rainfall was recorded, especially in Slovakia, which, however did not cause an above-average precipitation total. Flood waves caused by melting snow were characterized by short duration and not large volume III the degree of flood activity was exceeded in the Ipel' river, Slaná river and Hron river basins. Autumn in 2011 was exceptional for its drought. November has become the driest month in the history of meteorological measurements. Except for increase in surface water level after intense storm activity this year was compared to 2010 severely impoverished by floods [8].

\subsubsection{Year 2012}

In the period from January to April, ice floods and floods from melting occurred in our territory in the snow. In terms of the number of declarations III degree of flood activity was not a significant culmination. The period from May to August brought to the territory of Slovakia different total precipitation. The average height of precipitation in eastern Slovakia was 66 $\mathrm{mm}$. It did not occur in the Košice Region during this period flood not once, but in the Prešov region a flood was recorded in 16 cases. Six floods occurred in the addressed area of the Hornád river basin [8].

\subsubsection{Year 2013}

The year 2013 brought six flood waves. The first wave occurred in February, when it hit the south of the middle and eastern Slovakia in the Dunaj river, Váh river and Ipel' river basins. The second wave continued with influential heavy rainfall when the centre of Slovakia was hit. The period of Easter was marked floods in the Váh river, Nitra river, Hron river, Ipel' river, Torysa river, Olšava river and Bodrog river basins. Local floods in the third waves hit mainly the Morava river basin, but they also occurred in the Hornád river, Hron river and Ipel' river basins. Another wave caused a flood on the Dunaj river, and the last wave attacked in early June [8].

\subsubsection{Year 2014}

The first flood occurred in 2014 in March in the village of Hrabičov. Local flooding was caused by the spill of the riverbed Uhliarsky river. In addition to this flood situation, the first half of this year was significant exceptionally favourable flood situation. Rainfall activity later hit the territory of Slovakia in the month of May. Precipitation activity in this month exceeded values of two times monthly average precipitation. The second and third degrees 
of flood activity was declared in 163 municipalities mainly in Eastern Slovakia. The summer months were characterized by an uneven distribution of precipitation activities, mainly storm showers. Milder precipitation activity continued in the month September, and in October, a precipitation-runoff episode affected some river basins [8].

\subsubsection{Year 2015}

The floods caused in the first half of 2015 had the character of floods due to melting snow and flash floods. Eastern Slovakia was hit by floods, which were caused by warming along with severe ones precipitation activity. Later, floods were characterized by torrential character. From the report, the course and consequences of floods show that in the monitored period there were the most floods affected territory of eastern Slovakia. Despite the fact that the floods plagued Slovakia as well this year, the number of days with flood activity was 47 days, which is the least days of the year 2007 [8].

\subsubsection{Year 2016}

The beginning of the year was associated with the occurrence of ice phenomena. The flood situation hit the river basin the hardest Slaná river and Ipel' river, where, despite the winter period, liquid precipitation had its share in the occurrence of floods activity. In eastern Slovakia, an ice floe has formed on all watercourses. Influenced the rise in water levels in the Hornád, Bodva and Bodrog river basins began to increase significantly. In summer in months, flood situations were detected, especially in smaller streams due to high daily flows precipitation totals. Streams in eastern and western Slovakia were again affected by floods in October and November [8].

\subsubsection{Year 2017}

The beginning of 2017 had the same nature of the causes of floods as occurred in 2016. On the most streams freeze levels, created iceblocks caused swelling water levels. As in the previous year, there was a sudden warming in this year as well and subsequent melting of the snow. The floods occurred in the Bodrog river, Poprad river, Dunajec river and Laborec river basins. In early spring, flood activities caused heavy rainfall, which continued until mid-June.

Water levels increased in several watercourses. In the summer months, they again affected river basins of eastern Slovakia. From September to early November, several significant increases in water levels have been reported [8].

\subsubsection{Year 2018}

During the first half of the year, floods of various kinds occurred in Slovakia. During in the winter months, the Košice region was hit the hardest. The floods were caused by melting snow, but also due to rainfall activity. In March, it occurred in the Hornád river basin in the village of Kechnec to a significant increase in the level of the water flow, but subsequently the manipulation of the water flow was started sources at the Ružín river waterworks. Due to the hydrological situation, manipulation took place in the first half of the year on several water structures to ensure a smooth outflow [8].

\section{MATERIAL AND METHODS}

Flood risk assessment according to the FEIRA process (Flood Environmental Impact Risk Analysis) consists of the following steps [9-11]. The FEIRA process begins with a description of the current state of the environment and the definition of sources of pollution in the 
area. The next step is the identification of stressors - sources of risk that pose a danger in the assessed area and represent a potential impact on environmental components. The consequence is determined by the significance of the stressor's action on the selected evaluated component. The sum of the products of these two indicators is the obtained value of the risk index [2].

The IR (risk index) is measured by the product of the probability and the consequence of individual stressors expressed by the following formula:

$$
\mathrm{IR}=\mathrm{Pi} \times \mathrm{Ci} .
$$

The probability Pi expresses the value of each selected stressor effect and the consequence $\mathrm{Ci}$ expresses the value of the stressor effect on the individual components.

The value of the total risk posed by flooding in the event of floods is determined by the following formula:

$$
R=\mathrm{SUM}(\mathrm{Pi} \times \mathrm{Di}) \times \mathrm{Hi}
$$

The hazard Hi presents the sources of pollution in the river basin [5,7].

The result of this work is the proposal of measures for flood protection and a proposal document providing health and social care in the affected area in the event of its occurrence floods.

The crisis management and governance plan served as a basis for drafting the document. The starting point was also Act no. 7/2010 Coll. on flood protection, according to which some from the main points of the document outline. The main objective was to develop an integrated plan, which will provide health and social care to citizens in the event of floods.

Prevention and preparation, as well as this document, is a set of planning activities aimed at ensuring an integrated approach, in the event of a flood situation in the Hornád river basin is provided with health care in the given area - in case of increased threat floods - rescue and assistance to patients in health and social care facilities in relevant area.

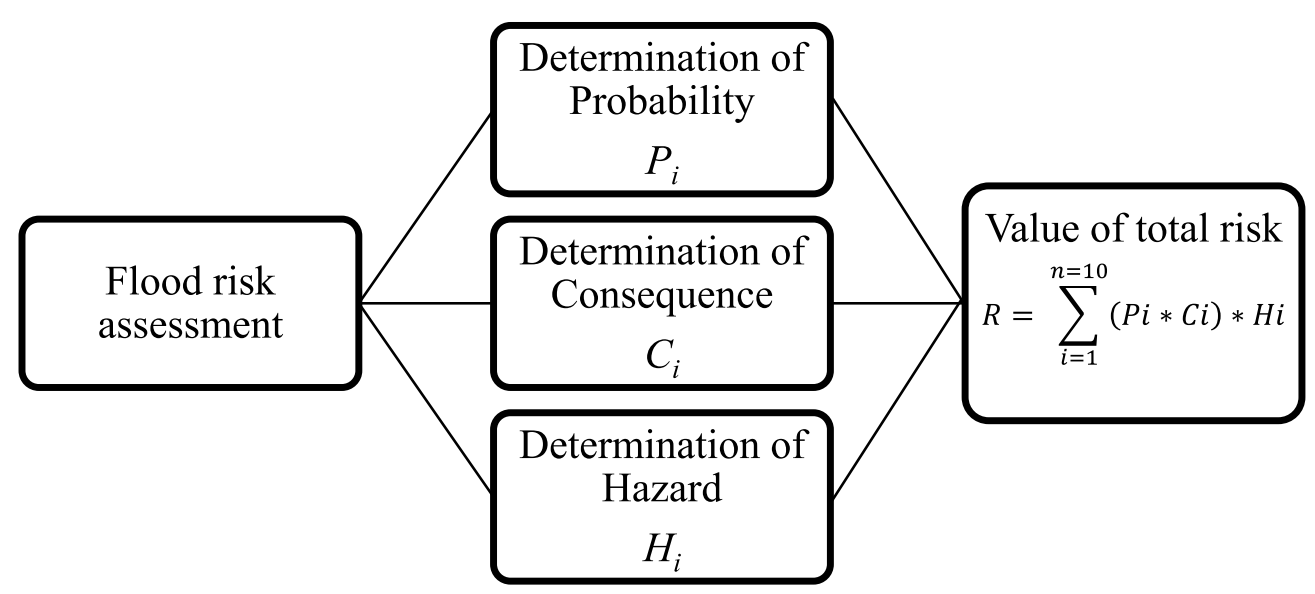

Figure 2: Flood risk assessment according to the FEIRA process. 
The following laws were used for the purpose of processing the protocol:

- Act no. 580/2004 Coll. on health insurance - this law establishes health insurance, legal relations arising from health insurance and redistribution of public premiums health insurance [12],

- Act no. 129/2002 Coll. on the integrated rescue system - this law regulates the organization integrated rescue system, the scope and tasks of state administration and rescue bodies components within the integrated rescue system, the rights and obligations of municipalities and other legal entities persons, natural persons entitled to conduct business and other natural persons in the coordination of activities related to the provision of assistance if life, health, property or environment [13],

- Act no. 461/2003 Coll. on the Social Insurance Agency - this law regulates the establishment, activities and organization of the Social Insurance Agency, financing and implementation sickness insurance, sickness insurance and pension provision. This law also regulates legal relations from the employer's liability insurance for damage at work accidents and occupational diseases and the provision of social liability insurance company [14],

- Act no. 7/2010 Coll. on flood protection - this law provides for protection measures flood protection and flood risk assessment and management obligations in order to reduce adverse effects of floods on human health, the environment, cultural heritage and economic activity; flood protection planning, organization and management; obligations and the rights of state administration bodies, flood protection bodies, higher territorial units and municipalities; obligations and rights of legal entities, natural persons - entrepreneurs and natural persons in protection before floods; liability for breach of obligations imposed by this Act [15],

- Act no. 42/1994 Coll. Act of the National Council of the Slovak Republic on Civil Protection of the Population - the purpose of this law is to regulate the conditions for the effective protection of life, health and property before consequences of extraordinary events, as well as to establish the roles and responsibilities of state administration bodies, municipalities and the rights and obligations of natural and legal persons in ensuring civil protection population [16].

\section{RESULTS AND DISCUSSION}

Probability is an expression of the possibility of the occurrence of a certain phenomenon. The starting point of this methodology is the qualitative determination of probability from the lowest value $=0.25$ to the highest value 1 . Level, resp. the probability value represents a certain expectation - whether the phenomenon will happen or can happen. How the negative stressor affects selected components of the environment is expressed by the consequence. It is expressed qualitatively - as well as probability.

All assessed effects with values of causes $P \mathrm{i}$ and their consequences $C \mathrm{i}$ are summarized in Table 1.

The analysis of individual stressors, which have a negative impact on selected components of the environment was described in the first part of this paper. It was determined for each stressor the likelihood and consequence of its impact. The values were then multiplied by the sum of the resulting values represents the resulting risk index IR $=5.5$. The overall level of risk in the addressed area. According to the proposed category, the Hornád river basin is determined by a value equal to 5.5, which represents medium level of risk [17]. 
Table 1: Summary of the probabilities and consequences of the impact of the flood on the environment.

\begin{tabular}{|c|c|c|c|c|c|}
\hline \multirow{2}{*}{$\begin{array}{l}\text { ID } \\
1\end{array}$} & \multirow{3}{*}{$\begin{array}{l}\begin{array}{l}\text { Impact of stressors } \\
\text { on components of } \\
\text { the environment }\end{array} \\
\begin{array}{l}\text { Impact of flooding } \\
\text { on the population }\end{array}\end{array}$} & \multicolumn{2}{|c|}{$\begin{array}{l}\text { Determination of } \\
\text { probabilities }\end{array}$} & \multicolumn{2}{|c|}{$\begin{array}{l}\text { Determination of } \\
\text { consequences }\end{array}$} \\
\hline & & $\mathrm{P} 1$ & $\begin{array}{l}\text { Local potential for } \\
\text { flooding }(-)\end{array}$ & $\mathrm{C} 1$ & $\begin{array}{l}\text { Health } \\
\text { consequences } \\
\text { of flooding } \\
\text { (point) }\end{array}$ \\
\hline & & 0.5 & medium & 1 & $\geq 5$ \\
\hline \multirow[t]{2}{*}{2} & \multirow[t]{2}{*}{$\begin{array}{l}\text { Impact of flooding } \\
\text { on water conditions }\end{array}$} & $\mathrm{P} 2$ & $\begin{array}{l}\text { Number of } \\
\text { announcements } \\
\text { of highest level of } \\
\text { flooding (per year) } \\
(-)\end{array}$ & $\mathrm{C} 2$ & $\begin{array}{l}\text { Capacity flow } \\
\text { Qn }\left(\mathrm{m}^{3} \mathrm{~s}^{-1}\right)\end{array}$ \\
\hline & & 1 & $>4$ & 0.75 & $\geq Q 50$ \\
\hline \multirow[t]{2}{*}{3} & \multirow[t]{2}{*}{$\begin{array}{l}\text { Impact of flooding } \\
\text { on soil }\end{array}$} & P3 & $\begin{array}{l}\text { The status of } \\
\text { flood protection } \\
\text { facilities }(-)\end{array}$ & C3 & $\begin{array}{l}\text { Permeability } \\
\text { of soil (-) }\end{array}$ \\
\hline & & 0.5 & Good & 0.5 & $\begin{array}{l}\text { Less } \\
\text { permeable }\end{array}$ \\
\hline \multirow[t]{2}{*}{4} & \multirow[t]{2}{*}{$\begin{array}{l}\text { Impact of flooding } \\
\text { on flora, fauna and } \\
\text { their habitats }\end{array}$} & $\mathrm{P} 4$ & $\begin{array}{l}\text { Local potential for } \\
\text { flooding }(-)\end{array}$ & $\mathrm{C} 4$ & $\begin{array}{l}\text { Vulnerability } \\
\text { of fauna and } \\
\text { flora and their } \\
\text { habitats (-) }\end{array}$ \\
\hline & & 0.5 & Medium & 0.75 & medium \\
\hline \multirow[t]{2}{*}{5} & \multirow[t]{2}{*}{$\begin{array}{l}\text { Impact of flooding } \\
\text { on landscape - } \\
\text { structure and land } \\
\text { use, landscape } \\
\text { character }\end{array}$} & P5 & $\begin{array}{l}\text { Local potential for } \\
\text { flooding }(-)\end{array}$ & $\mathrm{C} 5$ & $\begin{array}{l}\text { Changes in the } \\
\text { landscape (-) }\end{array}$ \\
\hline & & 0.5 & Medium & 0.75 & Significant \\
\hline \multirow[t]{2}{*}{6} & \multirow{2}{*}{$\begin{array}{l}\text { Impact of flooding } \\
\text { on protected areas } \\
\text { and their buffer } \\
\text { zones }\end{array}$} & P6 & $\begin{array}{l}\text { Local potential for } \\
\text { flooding }(-)\end{array}$ & C6 & $\begin{array}{l}\text { Location of } \\
\text { the proposed } \\
\text { activity (-) }\end{array}$ \\
\hline & & 0.5 & Medium & 1 & $\begin{array}{l}\text { Within } 3 \\
\text { and more } \\
\text { protection } \\
\text { areas }\end{array}$ \\
\hline
\end{tabular}


Table 1: (Continued)

\begin{tabular}{|c|c|c|c|c|c|}
\hline \multirow[t]{2}{*}{7} & \multirow{2}{*}{$\begin{array}{l}\text { Impact of the } \\
\text { flooding of the } \\
\text { territorial system of } \\
\text { ecological stability } \\
\text { (TSES) }\end{array}$} & P7 & $\begin{array}{l}\text { The status of } \\
\text { flood protection } \\
\text { facilities (-) }\end{array}$ & $\mathrm{C} 7$ & $\begin{array}{l}\text { Impacts on } \\
\text { TSES (point) }\end{array}$ \\
\hline & & 0.5 & Good & 0.5 & $6-10$ \\
\hline \multirow[t]{2}{*}{8} & $\begin{array}{l}\text { Impact of flooding } \\
\text { on urban areas and } \\
\text { land use }\end{array}$ & P8 & $\begin{array}{l}\text { Local potential for } \\
\text { flooding }(-)\end{array}$ & C8 & $\begin{array}{l}\text { Local potential } \\
\text { for flooding } \\
(-)\end{array}$ \\
\hline & & 0.5 & Medium & 1 & $\geq 101$ \\
\hline \multirow[t]{2}{*}{9} & $\begin{array}{l}\text { Impact of flooding } \\
\text { on cultural and } \\
\text { historical heritage, } \\
\text { intangible cultural } \\
\text { values }\end{array}$ & P9 & $\begin{array}{l}\text { Number of } \\
\text { announcements } \\
\text { of highest level } \\
\text { of flooding (per } \\
\text { year) (-) }\end{array}$ & C9 & $\begin{array}{l}\text { Number of } \\
\text { affected values } \\
\text { in the area (-) }\end{array}$ \\
\hline & & & $>4$ & 1 & $\geq 6$ \\
\hline \multirow[t]{3}{*}{10} & $\begin{array}{l}\text { Impact of flooding } \\
\text { on archaeological } \\
\text { and paleontological } \\
\text { sites and important } \\
\text { geological sites }\end{array}$ & P10 & $\begin{array}{l}\text { Number of } \\
\text { announcements } \\
\text { of highest level of } \\
\text { flooding (per year) } \\
(-)\end{array}$ & $\mathrm{C} 10$ & $\begin{array}{l}\text { Number of } \\
\text { affected sites } \\
\text { in the area (-) }\end{array}$ \\
\hline & & & $>4$ & 1 & $\geq 3$ \\
\hline & & $\sum_{i=1}^{n=10} I$ & & & 5,5 \\
\hline
\end{tabular}

According to the proposed category, the total risk level in the addressed area of the Hornád river basin is determined by a value equal to 5.5 - medium risk.

If a flood occurs in any area, it can also cause pollution of environment. There are several industrial sites in the Hornád sub-basin, which may pose a risk of environmental pollution in the event of floods. According to the categorization, each source of pollution is assigned the appropriate number of points - the $H$ i score (Table 2 ).

The sum of the values of individual causes and consequences represents the value $I R=5.5$, which is subsequently multiplied by the value of danger $H \mathrm{i}=19$. The product of these two values is the resulting value representing the total risk $R=104.5$. It presents very low risk for the Hornád river basin [10].

The goal of selecting effective flood protection measures in the studied territory include:

- the removing of soil deposits from the water channel and vegetation from the bank of the watercourse, thus securing the overflow capacity of the watercourse,

- for the unaltered sections of the watercourse to make modifications, e.g. to reinforce the slopes of the water channel, 
Table 2: Pollution sources with assigned number of points.

\begin{tabular}{|c|c|c|c|}
\hline $\begin{array}{l}\text { Category of source } \\
\text { of pollution }\end{array}$ & Source of pollution & Criteria & $\begin{array}{l}\text { Point evaluation } \\
\mathrm{Hi}\end{array}$ \\
\hline $\begin{array}{l}\text { Industrial } \\
\text { enterprises }\end{array}$ & $\begin{array}{l}\text { Area of VSE - enterprise } \\
\text { of mechanical production } \\
\text { Krompachy }\end{array}$ & Unclassified & 5 \\
\hline \multirow[t]{3}{*}{$\begin{array}{l}\text { Wastewater } \\
\text { treatment plants } \\
\text { (WWTP) }\end{array}$} & $\begin{array}{l}\text { WWTP Harichovce, WWTP } \\
\text { Vajkovce, AGROKOV PLUS } \\
\text { Košice, WWTP Rožkovany, } \\
\text { WWTP Jakubova Vol'a }\end{array}$ & $\begin{array}{l}<2000 \text { population } \\
\text { equivalent }\end{array}$ & 1 \\
\hline & $\begin{array}{l}\text { WWTP Spišské Vlachy, } \\
\text { WWTP Povodňového dvora } \\
\text { Krompachy, WWTP IMUNA } \\
\text { PHARM Šarišské Michal'any }\end{array}$ & $\begin{array}{l}2000-10000 \\
\text { population } \\
\text { equivalent }\end{array}$ & 2 \\
\hline & WWTP Spišská Nová Ves & $\begin{array}{l}10000-100000 \\
\text { population } \\
\text { equivalent }\end{array}$ & 3 \\
\hline Agriculture & Crop production & $\begin{array}{l}10-40 \% \text { of } \\
\text { flooded area }\end{array}$ & 1 \\
\hline \multirow[t]{2}{*}{$\begin{array}{l}\text { Environmental } \\
\text { burden }\end{array}$} & KOVOHUTY Krompachy & $\begin{array}{l}\text { Environmental } \\
\text { burden is likely }\end{array}$ & 3 \\
\hline & $\begin{array}{l}\text { SEZ Krompachy - enterprise } \\
\text { of electric production }\end{array}$ & Land reclamation & 3 \\
\hline \multirow[t]{2}{*}{ Urban areas } & Population without sewerage & $\begin{array}{l}10-40 \% \text { from all } \\
\text { population in the } \\
\text { study area }\end{array}$ & 1 \\
\hline & $\operatorname{Sum} \Sigma$ & & 19 \\
\hline
\end{tabular}

- if necessary construction of a reservoir above the town which lowers the maximum overflow during increased water stages.

The construction of reservoir - dry basin above the municipality seems to be the most effective flood protection measure in the area.

Based on the results of the FEIRA process, the output of this paper is a proposal document providing health and social care in case of floods is created.

The document contents these parts:

1. The legal background of health disaster management,

2. The health care system of affected area,

3. The social care system of affected area,

4. The relevant levels of health care management of flood situation in the affected area, 
5. The principles of disaster medicine management (CSCATTT),

6. COMMAND AND CONTROL - management and regulation plan for emergency alert of health care, national and cross-sectoral cooperation,

7. SAFETY - safety plan for the emergency-level alert of health care,

8. COMMUNICATION - communication plan for the emergency-level alert of health care,

9. ASSESSMENT - assessment plan for emergency-level alert of health care,

10. TRIAGE - triage plan for emergency-level alert of health care,

11. TREATMENT - treatment plan for emergency-level alert of health care,

12. TRANSPORT - transport plan for emergency-level alert of health care,

13. Alarm and confinement plan,

14. Plan for maintaining the provision in case of operation interfering circumstances,

15. Evacuation plan,

16. Rescue plan,

17. Seclusion plan,

18. Plan for setting up a moving medical post.

\section{CONCLUSION}

Floods are a natural element that we cannot completely control. The frequency of occurrence has last decades tend to increase. It is therefore necessary to expand the possibilities for flood protection, but it is also necessary to pay attention to flood management and flood risk management.

The first part of the practical solution of this paper was devoted to the analysis of individual stressors - floods, that have a negative impact on selected components of the environment. For each stressor impact, the probability and consequence of its effect was determined. The values were then multiplied by each other and the sum of the resulting values represents the resulting risk index. The risk index in the addressed area of the Hornád river basin is determined by a value equal to 5.5, which represents a medium level of risk level.

In the next part, the hazard was state according to the proposed methodology of Zeleňáková $[9,10]$ - FEIRA. In the solved area, sources of pollution were identified, to which a point value was assigned. The resulting value represented the sum of the partial results. In the Hornád sub-basin, a low threat rate applies with a hazard value is 19 .

The final part was devoted to determining the overall risk. The resulting value of risk is the product of the resulting values of probability, consequence and threat. According to the FEIRA methodology, the first category of risk level is estimated to 104.5, which means a very low level of flood risk.

The results achieved in this paper can be used as a basis for solving other problems concerning the effects of floods on selected components of the environment. In the analysis of stressors, it is possible to determine where the biggest shortcomings in flood protection are - e.g. why and for what conditions, degrees of flood activity were declared for the solved period, from which the numerical value for determining the probability of the technical condition of existing flood protection measures, and whether there are enough technical flood protection measures in the solved area.

Anthropogenic activity also needs to be considered. Many industrial sites in the studied area it poses a threat of pollution of watercourses in case of floods. Introducing more stringent measures to control this pollution must be considered. 


\section{ACKNOWLEDGEMENTS}

This work has been supported by the Slovak Research and Development Agency by supporting the project SK-PT-18-0008 and project SL-PL-18-0033. This work was supported by projects of the Ministry of Education of the Slovak Republic VEGA 1/0308/20 Mitigation of hydrological hazards - floods and droughts - by exploring extreme hydroclimatic phenomena in river basins.

\section{REFERENCES}

[1] Zeleňáková, M., Preliminary flood risk assessment in the Hornád watershed. WIT Transactions on Ecology and the Environment, WIT Press: Southampton and Boston, pp. 15-24, 2009.

[2] Zeleňáková, M., Flood risk assessment and management in Slovakia. WIT Transactions on Ecology and the Environment, WIT Press: Southampton and Boston, pp. 61-69, 2011.

[3] Mishra, K. \& Sinha, R., Flood risk assessment in the Kosi megafan using multi-criteria decision analysis: a hydro-geomorphic approach. Geomorphology, 350, pp. 1-19, 2020.

[4] Vojteková, J. \& Vojtek, M., Flood hazard and flood risk assessment at the local spatial scale: a case study. Geomatics, Naturaz Hazards and Risk, 7:6, 1973-1992, 2016.

[5] Tsakiris, G., Flood risk assessment: concepts, modelling, applications. Natural Hazards and Earth System Sciences. 2014.

[6] Ministry of the Environment of the Slovak Republic: Preliminary flood risk assessment in the Slovak Republic. Bratislava: MŽP SR, 2018. Available at: http://www.minzp.sk/ files/sekcia-vod/hodnotenie-rizika-2018/phpr_sr2018.pdf (accessed 5 November 2019)

[7] Slovak Paradise, [online]. <http://www.slovenskyraj.sk/strediska/phornadu/phornadu. html>

[8] Herl'any community, [online]. <http://www.obecherlany.sk/-narodna-prirodna-pamiatka-herliansky-gejzir>

[9] Správa o priebehu a následkoch povodní na území Slovenskej republiky, [online]. $<$ https://www.minzp.sk/voda/ochrana-predpovodnami/informacie/>

[10] Zeleňáková, M., Gaňová, L, Purcz, P., Horský, M., Satrapa L., Blišt’an, P. \& Diaconu, D., Mitigation of the Adverse Consequences of Floods for Human Life, Infrastructure, and the Environment, Natural Hazardous Review, 18, pp. 1-15, 2017.

[11] Zeleňáková, M., Gaňová, L. \& Purcz, P., Flood risk assessment as part of flood defence. SGEM 2012: 12th International Multidisciplinary Scientific GeoConference, Vol. 3, Albena, Bulgaria, STEF92 Technology Ltd., pp. 679-686, 2012.

[12] Zeleňáková, M., Assessment of flood vulnerability in Bodva catchment using multicriteria analysis and geographical information systems. WIT Transactions on Ecology and the Environment, WIT Press: Southampton and Boston, pp. 51-59, 2015.

[13] Act no. 580/2004 Coll. on health insurance, [online]. <https://www.zakonypreludi.sk/ $\mathrm{zz} / 2004-580>$

[14] Act no. 129/2002 Coll. on the integrated rescue system, [online]. <https://www.zakonypreludi.sk/zz/2002-129>

[15] Act no. 461/2003 Coll. on the Social Insurance Agency, [online]. <https://www.zakonypreludi.sk/zz/2003-461>

[16] Act no. 7/2010 Coll. on flood protection, [online]. <https://www.zakonypreludi.sk/ $\mathrm{zz} / 2010-7>$ 
[16] Act no. 42/1994 Coll. Act of the National Council of the Slovak Republic on Civil Protection of the Population, [online]. <https://www.zakonypreludi.sk/zz/1994-42>

[17] Zeleňáková, M., Šugareková, M. \& Mésároš, P., Flood environmental impact risk analysis. 2020. In: Urban Water Systems and Floods 2. Southampton (Vel'ká Británia): WIT Press (in press). 